\title{
Curriculum Reform and Practice Based on the working process "goods storage and distribution"
}

\author{
Guan_yafeng ${ }^{1, a}$,Mo_renbian ${ }^{2, b}$ \\ ${ }^{1,2}$ Chongqing College of electronic engineering, Chongqing, 401331, China \\ agyf-513@163.com ; 'bmrbian163@163.com
}

Keywords: working process, Course design, effects

\begin{abstract}
This paper explains the ideas and methods of the curriculum reform "Goods storage and distribution" based on the concept of the working process. Driven by working process of delivery, the teaching content take the working tasks as the core place, and the teaching method is oriented to guiding students to explore their own tasks. Obviously, it cultivates the student's comprehensive vocational ability and the employment rate is rising in Logistics professional.
\end{abstract}

\section{Introduction}

In recent years, with the rapid development of Chinese higher occupation technique education, the employment rate of graduates has continued to decline. According to the People's Daily reported: "the current national college graduates employment rate has continued to decline, down from $80 \%$ in 2001 to $72.6 \%$ in 2006, to less than 70\% of the actual employment in 2008.An important factor in the ordinary university graduate employment difficulty is the lack of occupation skill, and they cannot meet to the needs of the occupation market, nor our talents lacks of especially high-skilled personnel lacks, which is far failed to meet the demands of occupation education reality.

In February 25, 2009, the State Council executive meeting, considered and adopted the logistics industry restructuring and revitalization plan. The meeting proposed nine key projects, including multimodal transport and transport facilities, logistics park, city distribution, commodity and rural logistics, manufacturing and logistics industry linkage development, logistics standards and technology promotion, public logistics information platform, logistics technology and emergency logistics and so on.

Nowadays, a grim reality before us is: on the one hand, college students' employment rate continued to decline, and on the other hand, the social need high skill talents urgently. Obviously, the fundamental problem is the personnel training mode is not adapt to the social demand. How to objectively analyze the situation, and take effective measures to realize the occupation education "employment-oriented, competency-based training objectives" advancing with the times, has become a breakthrough in solving the contradictions between supply and demand.

"The goods storage and distribution" is a core curriculum of logistics profession, which is practical and paying attention to practice. How to make the students learn in doing is the first problem we should solve in the teaching reform. Therefore, we use "action-oriented teaching method" in "goods storage and distribution" course which is a pilot project in 2009. After the reform and exploration within more than three years, it has achieved initial results, which is a college quality course.

\section{Characteristics of “action oriented” Teaching}

Action oriented teaching method is a kind of teaching guiding ideology for the purpose of cultivating comprehensive occupation ability of students, which is brought into china in the late 1990's. Action oriented teaching, which is not a specific teaching method, but is a kind of teaching guiding ideology. It is composed of a series of specific teaching methods, such as brainstorming, card display method, case teaching method, COSPLAY method, project driven method, simulation teaching method and so on.

Action oriented teaching advocate "activities -oriented, competency-based training objectives", 
and compared with the traditional teaching in practice, it has the following characteristics: firstly, the changed the subject-object relationship between teachers and students. Students are actors in the activities, and teachers become organizer v instructor and consultant in the learning process from teaching knowledge. Secondly, students participate in the whole teaching process from information, planning, decision-making, implementation, inspection, evaluation. Thirdly, students play the main role, which inspire students a strong desire to learn, greatly improve their interest and thirst of learning. Finally, action-oriented teaching combined with "teaching 、 learning and doing," which is more close to the real occupation environment.

Through the "action-oriented", focusing on the student's professional skills (the skills and knowledge), methods, capabilities (learning to learn and work), social skills (learning to live together and life) combining training and ultimately improve their professional capacity, by the "professional skills "to" professional qualification "to" professional capacity "across.

\section{The application of the action-oriented teaching in "goods storage and distribution"}

\section{Teaching content organization}

According to the logistics enterprise surveys, and job task analysis of logistics management, goods storage and distribution is mainly used in three areas: manufacturing enterprises, distribution enterprises, and Express industry, In the design of "goods storage and distribution" courses, considering distribution business process as the main line, according to the working process of logistics activities to design the teaching content, and according to the distribution of the work flow to determine the order of curriculum content, realizing integration of skills and theoretical knowledge, So that students can complete independently or with others a single or integrated distribution management tasks, and complete the task of the effects of scientific reasonable assessment.

Based on the situated cognition theory and the advanced experience of Germany curriculum development study based on work process, the famous occupation education expert Jiang Dayuan pointed out that: learning environment in learning small topic areas within the framework of learning unit. Through the investigation and analysis of the enterprise logistics management of the typical tasks, according to the distribution service subject as the carrier, divided the "goods storage and distribution" teaching content into 3 learning situations: for business enterprise distribution, for production - oriented enterprises distribution; for consumer distribution (express parcel delivery). Every learning situation is divided into different learning modules in accordance with the specific process of distribution, such as express parcel delivery including order processing, receiving operation, an express mail sorting, transit, delivery receipt operation, information processing operations, and the claim work. Each unit of study is responding to solve a business aspect of theoretical knowledge and practical skills, the learning unit has its own system, and related. The learning Unit in different learning situations there will be repeated, students are familiar with every link operation in repeated learning.

\section{The design of teaching process}

"The goods storage and distribution" is very practical. The students are required to learn the theoretical knowledge, but also master the practical skills, at the same time, students are required to have the ability of autonomous learning and the idea of lifelong learning because of the information technologies are quickly updated. The traditional teaching mode is only theory teaching in the classroom, and dull explanation cannot improve the learning interest of the students. We just see the equipment such as forklift、 Pick-to-Light systems from pictures, video. Students cannot use it in practice. Traditional methods cannot meet the development of logistics technology.

The steps of teaching process are Information, planning, decision-making, implementation, examination, evaluation. (1) The students make clear the task. The teacher assigned task, help the students to understand the mission requirements. (2) plan. Students are generally in the form of group work, find task-relevant information, and make plans. (3) Scheme decision. Through brain storm, Students argument and make decision, which form a team project. (4) The project 
implementation. Students complete the design and simulated according to the plan, prepare the relevant written records. Teachers guide students in the learning process, help students' learning bias correction. (5) Check control. The students check and showing work. (6) The evaluation feedback. The students' self-evaluation, mutual evaluation, Students master the operation skills through the six step, in response to a change in occupation work. Through the 3 situational learning design training, analyze problems, problem-solving, teamwork has been integrated into the whole process of teaching, students access to information, planning, implementation plan, assessment program independently, grasp the occupation skill, learning professional knowledge, so that build their own experience and knowledge system, Which lay a solid foundation for engaged in warehousing, distribution and other work in the future.

\section{The effects of teaching reform}

In the past two years graduates employment in the storage industry has increased year by year in our university, According to statistics , our one-time employment rate of graduates reached $96.41 \%$, employers of graduates is higher, qualified rate to more than $90 \%$.It is believed that the curriculum reform played an important role.

Students grasp the different vocational skill in the 3 situational learning designs so they can apply professional knowledge quickly in enterprise. Students repeated practice in the six steps in “action-oriented" teaching, so they can learn the business quickly and well done.

\section{Summaries}

The work-oriented curriculum is the inevitable choice of training high skilled talents which is proved by our practice. Based on the working process of the "goods storage and distribution" curriculum, development and teaching practice, focusing on improving the core of teaching quality, has started from the course construction and reform, to strengthen the practice of teaching process, and occupation as the breakthrough point of the reform, let the students learn comprehensive occupation ability in near real occupation environment, change the traditional teaching mode. The reform will greatly stimulate the students' learning interests greatly, and promote the interactive of teaching process obviously. Spread and application of the curriculum model will effectively promote the innovation effectively and reform of the personnel training mode, improve the overall teaching quality. Action oriented teaching is an effective teaching method in Higher vocational education.

\section{References}

[1] M. Zhou, F.H. Huang, 1.F. Li, "Logistics teaching reform and innovation based on KAQ fostering goals," Storage, Transportation \& Preservation of Commodities, vol. 30, January. 2008, pp.123-124.

[2] Dayuan Jiang, M. Contemporary German Vocational Education Mainstream Teaching Ideology Research. Tsinghua University Press, Beijing China.(2007) (Chinese)

[3]QuanQuan Wu, J Vocational Development Trend Vocational Education Forum, Beijing China.(2004) (Chinese)

[4]McDonough, J.\&C. Shaw. Materials and Methods in ELT. A Teachers' Guide. Cambridge and Mass: Blackwell. (2003).

[5] Wen Yan Zhang, The course design for Logistics Information Management based on the “work process” IEEE CONFERENCE PUBLICATIONS, Aug 2011, Pp7345 - 7348 